\title{
ENVIRONMENTAL CONSCIOUSNESS
}

\author{
By: Oene Schreuder*
}

\section{Abstrak}

Artikel ini akanmembabas berbagai aspek pertanggungjawaban lingkungan secara global. Artikel ini akan dinilai dari pandangan-pandangan dasar melalui pandangan-pandangan personal sampai pada saran-saran terbaik dengan pendidikan lingkungan. Tulisan ini bukan basil dari sebuab penelitian oleh karena itu di dalamnya tidak ditemukan anama penulsi atau pengarang. Tulisan ini dibarapkan memiliki relasi tersendiri bagi doktrin keagamaan, artinya babwa relasi antara lingkungan dan agama (eco-teologi) dijelaskan dalam artikel ini. Meskipun dalam tulisan ini penulis lebih banyak mengajukan pertanyaan dari pada jawaban, namun demikian penulis berbarap ide-ide penulis dapat diimplementaikan dan dapat menjadi motivasi bagi pembabasan selanjutnya.

\section{:}

تحاول المقالة المالية مناقشة الأبعاد المختلفة لمسؤوليتنا البيئة بشكل عام، وذلك انطلاقًا من رؤى العالمه عبر بعض الاعتبارات الشتخصية، وصولاً إلى زوج من الاقتراحات حول "التعليم البيئي" . يأمل الكاتب بذللك أن يوضَح العالقة بين الدين والبيئة، كما يرجو أن يتمكن القارى أن يطبق موجبات تللك العلاقة بعد قراءته لتلك المقالة. كما يستميح الكاتب القارى عذراً إذا كان أسلوب المقالة المالية يغلب عليه طرح الأسئة دون الإجابة عنها، لكنه يأمل أن يدفع مثل ذلك الأسلوب إلى مزيل من المناقشات والبهحث العلمي.

Keywords : view on the world, macro- and micro-ecology, learn to love the earth.

* Oene S.H. Schreuder, Mpd. is since 2001 a Dutch guest-lecturer at the Faculty of Education, Department of Special Education of the Yogyakarta State University. He also teaches language at the Faculty of Social Sciences. Before, he was more than 20 years a school-teacher in primary, secondary and special education in the Netherlands. His expertise is focused on the so-called: "Inclusive Education for disabled childrenJl. Sekar Dwijan 3 Yogyakarta-Indonesia Telp (0274) 633316 


\section{A. Introduction.}

At the moment that the American astronauts were on their journey to the moon, one of them (Armstrong) expressed, that, looking out of space, he was amazed of the beauty of the "lovely blue planet" beneath him. It seems, that for the first time people (also worldwide by television) were looking with different eyes at the preciousness of the vulnerable, lovely blue planet', their home!

At the same occasion he also remarked, that, however they had a feeling of eternity in the wide space, they had not yet met "God" out there. These remarks are significant for the modern times, in which technical progress goes hand in hand with a reduction of religious conviction. "If mankind is already able to conquer the space and land on the moon, why should we longer believe in an omnipresent God, who is invisible and not scientifically to be proven? ", could have been the mindset.

Actually, this big historical event was ushering a new era in the awareness of planet-conservation and the upcoming environmental movement in the late 60-ties. The 'Report of Rome', concerning the threats of the devastation of our planet, became the alarm-bell. I want explicit these remarks a little bit more in order to approach my above -mentioned subject.

\section{B. The Four Realms of Creation - The gifts of God.}

When God created Earth, there were four realms provided, which were to be divided In:

1. the mineral,

2. the vegetative,

3. the animal,

4. the human.

God gave the task to the human beings to make USE of first three, and at the same time to take care of it. The mineral world is the world of stones, including the mineral resources, like iron, oil and every thing, which could be delved. We might as well add: water and air, because these also consist of mineral elements. The vegetative is the world of plants, trees and everything, which is growing in a certain biological envitonment (biotope). The animal world contents all animal species from the most simple until with the most developed. There is a strong relation between all 4 realms; none of them can exist on its own, except for the mineral. Minerals are locally subjected, so to say: "dead objects".

Plants are also locally bound, but are "growing, living and somehow breathing creatures" Animals are moving (although bound to a specific habitat), growing, breathing and living creatures, they do not "think, but have to "obey" their instincts. However the higher developed animal creatures posses a 'soul' (Latin: animus=soul) , this soul is still a so called "group-soul", which is primarily focused to react on the 
signals and conditions of a defined environment.

The human being is "free", not bound to a certain environment. He differs with the animal realm, because he is thinking and able to create. That is why he is standing upright (homo erectus') and able to use his hands to create, not only for 'forwards-moving', like all animals do. Human beings are also "free", because they are able to deny their (group-) instincts: which gives him the possibility to become an individuality.

In fact human being has all three other realms incorporated in it-self: We have bones consisting of minerals, We have a breathing system, similar to the vegetative world, We have our surviving instincts, and we also have obvious elements of the group-soul, similar to the animal wotld, But, above this we are gifted with thinking, imagination, and spirituality;

This last, fourth component makes us superior to the former three realms and simultaneously makes us responsible for the lower three realms. With this in mind we come back to our topic: environment and religion.

Use and abuse of what the world is offering us.

We stated, that the human being is disposed with consciousness, awareness of what he is doing. However, in practice this not for $100 \%$ true; for a great deal we live on our instincts and are handling things almost automatic. From the moment, that I wake up in the morning, until I reach the campus-site, I don't have to "think" so very hard. I wash my self, have my breakfast, use my transport etc. etc., day in ,day out I can rely on my previous experiences, my habits, so to say my "underconsciousness".

But in principle we can reflect on what we are doing,, we can make a change and we can create a new way of doing, living. So, what about my relation to the environment? Am I constantly aware of how I am affecting the world around me? Or in other words, that I am using well, or rather abusing the riches of the earth? The borderline between right or wrong, good use or abuse, is often very thin.

I give an example:

If I eat my daily rice, I'm not always thinking of: the origin of the product, the farmer, who planted the rice-plants, working under the burning sun and in the heavy earth of the rice-fields, the sun and the rain, which make the seeds growing.

(Perhaps I would remind these in my prayers before eating.my meal) I am not even thinking of the fact that the farmer has to use fertilizers, with possible environment-endangering chemicals. Usually, it is enough for me to go to the shop, find a good price for the product and hope that it's quality (taste) doesn't disappoint me.

My consciousness is not going that deep.

Another example:

If I buy a pencil in the shop, I do the same thing: I look at the price, the quality 
and features of the product. May-be this pencil is good for about 1 year, and than I have to buy a new one. Again, my consciousness about the origin (production) of the pencil is not so very much involved. But if I take a closer look, I might conclude the following: The wooden part of the pencil is made of trees (probably tropical rain-wood trees of Kalimantan), The leaden part of the pencil could have its origin from Russian mining. The paint on the outside of the pencil could have been produced using an oil-paint product from the USA. Just buying one simple pencil connects us with the whole world! It is nowadays not possible to demand only national products; Mostly without our awareness, we have daily consumption (=connection) of many products, which have a foreign origin. This is an effect of what we call: "globalization".

Of course, as consumers, we have the right to select our products well, but it doesn't make sense to think, that a single person or nation could stand on his own; In fact, we are very dependent on international resources, producers, transporters, retailers and so on. As consumers we are the last link in the chain. How important this is, we can hardly imagine, but it is without any doubt, that the consumers have the most powerful role in the circle producer-consumer. And the highest responsibility! There is a statement, which says:" if we buy just one simple wooden pencil, we should hear one tree falling cut down!" (a true fact, because we are responsible for initiating a process). The 2 examples above are concerning mineral and vegetative sources; We could easily extend this to the consumption of animal products: If I eat a piece of meat, than do I think of all circumstances, under which the animal is grown up? Do I think of the farmer and slaughter, who play an important tole in the food-production?

Not always! Perhaps a vegetarian is more conscious about these things, which make him decide to not consume animal food, because he cannot accept the 'suffering of the bred animals'.(Or is a vegetarian just worrying about his private health ?)

Anyway, we can look from different points of view at 'the proper use' of the earth-riches .

\section{Eco-religion.}

Now I would like to continue on how we can 'take good care of' (preserve) our planet. Since the scientist Newton' described the laws of gxavitation, he was probably not aware, that he was evoking a complete new view on the world, merely based on the physical laws. Spiritual influences became doubtful, and were not longer rewarded as:

'scientific' arguments.

We can see this for example in the development of medical science:

The human body is regarded as a complicated 'machine', the heart is a kind of 
mechanical pump, the brains are a kind of sophisticated computer. We cannot deny the gain of the huge evolution in nature-sciences; people are able to approach problems by thinking in 'exact' terms, the research in all disciplines of science made an enormous progress, we can even conquer the space!

Also the other, such as psychological and social sciences took their advantage - of the modern insights, however they became primarily based on the paradigm's and research-methods of nature-science.

We could state that the 'soul', (the spiritual and theological aspect) in science is not longer alive. Eventually, we have become very smart in 'calculating investigation':

We can measure with what speed an apple is falling from a tree, but the question "why" and "how" it is possible, that an apple is growing on a tree is not a scientific "item" anymore, because this is a spiritual theme and doesn't lead to 'scientific evidence' The conclusion is that we are 'rich' and 'poor' at the same time. In earlier days people were still conscious of the 'spiritual' values in nature.

They worshipped tocks, trees and animals as spiritual manifestations of the higher world (Animism). They tried to live 'in balance' with nature and took 'good care' of it all. Eco-theology was not a matter of scientific study, but a way of living. Mankind in former times still had a 'holistic' view; they were making use of the earth' riches and simultaneously taking care of it.

They were regarding life as a big "continuum": not only thinking selfishly, but also about the lives of their children and grandchildren. And since believe in reincarnation was wide-spread ( $70 \%$ of the people on earth still do), people were also concerned about their next life on earth. (In this framework we could discuss the question, if a too strong focus on the believe in 'the end of times' ('Kiamat') is rather apologizing people for the current destruction of the earth in stead of inspiring us to preserve our planet)

Unfortunately we cannot go back in the past: movements, like "back to nature" or "small is beautiful" are not a realistic answer on the current problems, which we are facing in our relation to nature.

We have to involve modern science, modern techniques in our efforts to manage the environmental problems. We have to look at things from a global point of view.

And most of all: we constantly have to be conscious about' why' and 'what' and 'how' we are doing : what are the assumed consequences, the effects on large scale and for the long period? The good use and the abuse, the good care for the future? That is everybody's responsibility; not only the producers (industry) or the government. And the modern information-era gives us the possibility to become 'aware' of facts behind it all. 
It also 'sharpens' our way of thinking; our intellectual competences could also be applied to spiritual considerations. The word "re-ligion" actually means: re = a new, ligare $=$ relate, in other words: Create a new relation with the spiritual reality.

This is not only limited to our personal, straight relation to God (by praying), but also includes our relation to the three lower reigns(see above), which also should be respected as god's creation .

Just for example:

Would it be possible, that if we use a factory-made pencil, we still will be conscious about the spiritual side of this simple material ? If we eat rice, would we remind the spiritual origin of this plant? If yes, we are speaking about 'eco-religion' in narrower sense, according to my opinion.

\section{Religious Eco-Education.}

It is clear that education has a great task in getting conscious about our environment. Yet, it should be implemented in a proper way. The attitude of children is a sensitive one, they are easily to be influenced. What we can 'invest' today in young people, will be fruitful in the future. Like in all subjects in education we really have to be aware of 'why, what and how' we are bringing our programs. For example, I don't think, that it makes sense, if we 'burden' our young children too much by confronting them with the many human failures made in the environment. All these big calamities could make them pessimistic and angry for two reasons:

1. Children in the school-age are not yet ready to fully understand the relation between the causes and the consequences;

2. Children are inclined to react impulsively; if they see injustice or suffering, they immediately want to do something about it. And in many cases of envitonmental disasters they simply cannot do anything, because they don't have the means and competences for it. That works out frustrating.

So, what kind of curriculum-contents we should prefer to bring in our schools? In my opinion, the keyword for environmental education is: "Teach the children to love the earth and all what lives on it". This is nothing less than a religious command! And, this is not a vague message; there are many ways and things, which are appropriate to realize this magnificent educational target.

I doubt, if a weekly sweeping of the S.D-schoolyard has something to do with environmental education. But it is still better than teaching the children out of theoretical learning-books, in which they learn (?) so called scientific concepts of nature. The contents of the many schoolbooks are only meant for cognitive memorization and hardly inspire young people to find an emotional relation to their envitonment. It is better to spare these science-oriented subjects for he secondary levels 
of education, where this could become background- theory supporting the practical study of nature.

If we want young children learn to love the earth, we should conduct a spiritually- based approach. We should appeal to the 'soul', the hearts of our children. How might this be done? Children in the primary school-age are in the first place busy to discover the world, beginning from the smaller environment to the larger. They learn with triple $\mathrm{H}=\mathrm{Head}$, Heart and Hands, or the three aspects: cognitive , emotional and motor-. Learning always starts with the last two: this is what we call a "psycho-motor-", or operational learning-approach".

Best results in education are achieved by "Learning by Doing". This means, that we should give them room to discover and experience as much as possible, before we attach the 'dead' intellectual definitions and axiom's. A school- book with a written explanation of the co2- oxygen-assimilation of trees (in scientific terms, class $3 \mathrm{SD}$ ), has no educational value . It becomes: "dead knowledge". Not to speak about the non-emotional impact.

Instead of that, why not organize experiments, small nature-projects (gardening etc), in which all children, also the less-intellectual-talented can participate ? This also offers many possibilities for the very needed social interaction in education: working together in a project is far more social than learning social rules out of a school-book.

Another keyword for all kind of education in primary levels is the "artistic approach":

The emphasis in the general development of children in the lower school-age is still laid on emotional growth (EQ). This is fundamental for the later cognitive development. In other words: "smart brains, without a good emotional balance, is a not required situation". It can even become dangerous. If we are able to transform our education-model towards an "artistic" way of learning, we already could support the emotional needs of children.

How? By implementing many art-activities in education, so that the heart and hands are sufficiently involved. We can learn about our world by way of: singing, drawing, painting, theater, designing and taking care of an eco-environment-project, even mathematics could be taught on an artistic way. Art should not be regarded as 'lost time', because the results are sometimes not measurable in school-notes.

Art is a highly legitimate component of our society, which can become a spiritual counter-balance for the one-sided materialism with all its negative aspects for our eco-system. Eco-theology will not be a merely academic discussion, but can become contributive to human and earth, if we are capable to incorporate it in our daily-life, starting with education. 


\section{E. Conclusion:}

I hope this article contributed to the theme of this edition of Millab. Religion and Environment are not to be separated entities. The science and study of both could raise our consciousness in all aspects of: "Quality of life and life-hood"; In education we șhould adjust our targets (environmental awareness) to the psychological development-stages of the target-group. If we are able to plant love for the earth in the hearts of children, we are applying religion in a concrete way. To come back to the introduction-story of the Apollo-astronauts, two things:

1. People think, that we have landed on the moon, which is partially true; but the astronauts went to the moon in a very earth-conditioned 'cocoon', and have never been disconnected with the life on earth. In other words: "they just brought a little piece of earth to the moon".

2. The most famous astronaut Armstrong made a radical change of mind after his space-flights: he became a well-known activist in peace-movement and also an 'advocate' for environment-preservation.

He eventually got inspired by religious introspection!

\section{BIBLIOGRAPHY:}

Bakker R. Dr. (1964) The History of Phenomenological Thinking, the Netherlands: Aula Het Spectrum.

Beck H.L. and Kaptein N.J.G. (1988) Pandangan terhadap Literatur Hukum Filosofi Teologi dan Mistik Tradisi Islam, Jakarta: Indonesian Netherlands Cooperation in Islam Studies (INIS).

Berg van den J. Dr. (1972) Geneeskunde Op Dood Spoor, Nethetlands: LemniscaatRotterdam.

Forth Gregory (1998), Beneath the Vulcano, Religion, Cosmology And Spiritual Classification Among The Nage Of Eastern Indonesia, Netherlands: KITLV Press.

Lievegoed B. Dr. (1947) ontwikkelings-fasen van het kind development-phases of children, Netherlands: Uitgeverij Vrij Geestesleven, Zeist.

Steiner R. Dr. (1924) “Allgemeine Menschenkunde, Stuttgart-Germany: Verlag Freies Geistesleben. 